24 Магид Н. И. Отчет о работе Госарбитража за 1944 г. Январь 1945 г. Л. 3.

25 Арбитраж в СССР / Под ред. А. Ф. Клейнмана. М.: Изд-во Московского университета, 1960. С. 11. Во время войны на совещаниях в Ленинградском городском госарбитраже приглашенными экспертами высказывалось мнение, что «арбитраж не является административным органом, органом управления, т. е. ему не принадлежит административная власть и право распоряжения... [но] ему принадлежит также право контроля и, в связи с этим, право сигнализации о неправильностях в деятельности тех или иных хозяйственных органов» (из выступления Л. И. Фишмана)- (Протокол совещания юрисконсультов в Госарбитраже при Исполкоме Ленгорсовета, 09.07.1944 // ЦГА СПб. Ф. Р-9621. Оп. 1. Д. 13. Л. 1,1 об.).

26 Решение Исполкома Ленгорсовета от 16 сентября 1944 г. № 123-9 «О работе Государственного арбитража» // ЦГА СПб. Ф. 7384. Оп. 18. Д. 1567. Л. 26. Судя по всему, данное решение исполкома Ленгорсовета было обусловлено принятым ранее - 11 мая 1944 г. постановлением СНК РСФСР № 401 «О работе органов Госарбитража РСФСР», которым предписывалось : «1) < ..> в) сообщать облисполкомам, крайисполкомам, совнаркомам автономных республик, народным комиссариатам и руководителям хозяйственных организаций о выявленных недочетах в деятельности подчиненных им хозяйственных органов и предприятий (нарушения режима экономии и финансовой дисциплины, факты бесхозяйственности, недостачи товаров, вопросы качества продукции и т. п.), вносить предложения по устранению этих недочетов и сообщать органам прокуратуры в необходимых случаях о нарушениях закона для привлечения виновных к ответственности $<\ldots>$ 4. Обязать народных комиссаров, руководителей ведомств и учреждений РСФСР принимать меры к устранению недочетов в деятельности подчиненных им хозяйственных организаций и предприятий по материалам государственного арбитража, и о принятых мерах сообщать соответствующему органу государственного арбитража» (http:// lawru.info/dok/1944/05/11/n1194180.htm_(дата обращения 03.05.2019)).

27 Отчет о работе Госарбитража за 1943 г. // ЦГА СПб. Ф. 9621. Оп. 1. Д. 11. Л. 18-20, 24.

28 Магид Н. И. Отчет о работе Госарбитража за 1944 г. Январь 1945 г. Л. 18.

\title{
Alexis Peri
}

\section{Lessons of the Leningrad Blockade: Schoolchildren's Diaries as Sites of Learning, 1941-1943}

When describing the incomprehensible circumstances in which they found themselves, the blokadniki relied on several metaphors. The most famous of these were "the ring," which conveyed their state of encirclement, and "the island," which expressed their isolation from the mainland (большая земля) 
of the USSR. But there was another set of metaphors, less often discussed, that Leningraders evoked when articulating the monumental task of survival. This was the idiom of schooling - trials, tests, lessons, and learning ${ }^{1}$. The Blockade was “крутой экзамен и надо его выдержать," one siege diarist explained ${ }^{2}$. The siege would reveal whether Soviet people were sufficiently prepared - physically, mentally, and ideologically - to withstand this assault on their nation and its revolutionary project. Anticipating the important roles that Leningrad schoolchildren would play in the city's defense, one teacher remarked in her diary: "Сейчас и учителя держат строгий экзамен, кого они вырастили и воспитали?”3 If Leningrad and Leningraders were to survive, they had to adapt. This involved both learning - new skills, trades, and habits of mind - as well as "unlearning (разучиться)". Eighteenyear-old Nina Erokhana called besieged Leningrad "a great school (большая школа)", and explained that she was keeping a diary to record the perilous lessons it imparted: "Когда буду перечитывать [дневник], всё будет вставать перед глазами и напомнить мне это тяжелое время. И я хочу этого, так как это большая школа. Это время многому научила, и я не хочу этого терять” ${ }^{4}$. War was a great educator.

Although metaphors of learning proved central to the siege experience, when Hitler's troops invaded, it was unclear how much formal education would be prioritized in light of the exigencies of war. Initially, some state and party officials argued that "сейчас не до учебы” and were quick to requisition school buildings for military use. Others, however, fought this "politically myopic" attitude with a series of directives to enforce enrolment, attendance, and vigilance on the educational front. Sovnarkom (Council of People's Commissars) demanded that city authorities "draw all school-aged children into schools and keep them there" in order to protect pupils and instill patriotic values in them ${ }^{5}$. Signs and placards inside Leningrad urged young blokadniki to attend school as part of their contribution to the city's defense. “Каждая пятерка - снайперский выстрел по врагу”, one banner read. A fighter jet bearing the name "Leningrad Student" carried this message to the front ${ }^{6}$. Education, especially the task of raising young people to be ideal Soviet citizens, had always been central to the Soviet project, but during WWII it became bound up with the defense of the USSR ${ }^{7}$.

The fact that Leningrad's school system continued to function throughout the siege has emerged as a key metric of the blokadniki's successful defense of their city. Historian John Dunstan has pointed out that "beleaguered Leningrad" is "the most celebrated case by far" of Soviet wartime schooling8. Leningrad's schools and its schoolchildren have come to symbolize the city's vitality and the defiant triumph of normal life there ${ }^{9}$. While schoolchildren did many essential tasks - they took on defensive labor, volunteered in hospitals, and extinguished bombs - "И самый великий подвиг школьников Ленинграда”, famed writer A. A. Fadeev proclaimed, 
“в том, что они учились. Да, они учились, несмотря ни на что”10. Similarly, war correspondent Alexander Werth painted a picture of a "typical" besieged classroom in his 1944 classic Leningrad, where the students of School N367 aced every subject they studied "in the hard life of school"11. "Главный экзамен они уже к тому времени выдержали - испытание первой, самой страшной блокадной зимой”, that school's director, Iakov Kamenetskii, echoed ${ }^{12}$.

This essay explores Leningraders' steadfast devotion to wartime education as part of the larger notion of the Blockade as a test and the besieged city a kind of school. The questions driving this essay are: What did education - including its academic, ideological, and socializing functions - mean to Leningrad students? How did they describe the experience of attending school, transformed by wartime conditions? To what did extend their commitment to education strengthen their fight for survival and to what extent did it conflict with it?

The main source I draw upon are wartime diaries. As a form, the diary has a special relevance both to Soviet education and to the Blockade. Generations of Soviet people learned to keep journals in school. It was a tool for developing their writing skills and for helping teachers and pupils monitor their academic and personal development $^{13}$. Moreover, shortly after the city was encircled, city party authorities launched a campaign encouraging Leningraders to keep diaries, so that future generations might understand their experiences under siege $\mathrm{e}^{14}$. During the Blockade, schoolchildren kept journals both individually or collectively with their classmates. On holidays and inspection days, these accounts were exhibited to visiting state and military leaders as evidence of patriotism and high morale among young blokadni$k i^{15}$. The most famous exhibition of a Leningrad schoolgirl's diary was the journal of Tania Savicheva, read at Nuremburg to prove the Blockade was a war crime.

Students' and teachers' wartime journals allow us to look inside blockaded classrooms, to access their reception of the wartime curriculum, and to evaluate how diary writing, which had long served as a tool for self-betterment, acquired new meaning under siege. The diaries illuminate a key tension between intellectual and physical survival, between self-transformation and self-preservation. On the one hand, the diaries suggest that education was essential to survival. Schools provided physical sustenance, meals, to students and teachers. They also offered intellectual stimulation and companionship, which nourished Leningraders morally and spiritually. Diarists who maintained an enthusiastic attitude toward learning - whether inside or outside of the classroom - acquired both practical skills as well as mental fortitude. Moreover, the circumstances of the siege infused familiar academic subjects with new meaning. The diary provided a space for independent, supplementary study. In his landmark study of diaries from the 1930s, Jochen Hellbeck argued that the diary was a central tool for the Soviet project of perfecting the self, of reaching one's fullest potential as a Soviet citizen ${ }^{16}$. The students' earnest commitment to continue their education during the Blockade demonstrates that "work on the self" endured, even in extreme conditions of starvation and deprivation. 
On the other hand, the Blockade greatly disrupted formal education. Students and teachers described in their diaries how city schools were unable to fulfill the scholastic, ideological, and social functions of education, compelling pupils to modify or create their own programs of study. Thus, young Leningraders worked outside of the official spaces and authority of Soviet pedagogy to fulfill the regime's didactic mission. The diary temporarily replaced the schoolhouse as a site of erudition. Such independent learning was intellectually nourishing, but it was also mentally taxing. By pursuing their studies, the diarists diverted both material resources and energy away from the hunt for food that was absolutely imperative for immediate survival ${ }^{17}$. In this way, the diarists were torn between impulses to work on the self and simply to preserve it.

Below, I focus on just a handful of diaries and on the first two school years, 1941/1942 and 1942/1943, when the school system was most in flux. These academic years also fell between two major sets of education reforms in 1939-1940 and 1943-1945. By mid-1943, Leningrad's City Educational Department (GORONO) had regained substantial control over schooling.

\section{Going to School Under Siege}

The Stalinist ideal of a highly centralized and standardized school system was an early casualty of war $^{18}$. Mobilization, evacuation, bombardment, and shortages created upheaval among educators ${ }^{19}$. In Leningrad alone, more than 180,000 teachers were mobilized to the front ${ }^{20}$. Leningrad's schools also were among the most devastated in the Soviet Union. While the USSR lost $43 \%$ of its schools, Leningrad lost about $90 \%$ of them. German troops launched more than 148,478 artillery attacks on Leningrad, and they made no effort to spare Leningrad children ${ }^{21}$. Directive 736, for example, ordered the bombing of School N 105 on Baburin Pereulok, and Directive 192 targeted the Pioneer Palace on Nevsky Prospekt. In May 1941, an estimated 374,876 Leningrad children were enrolled in 476 schools. At the (delayed) start of the academic year in November 1941, 103 schools served 90,000 children. By January 1942, however, only 39 schools and 12 shelters operated for 35,964 children ${ }^{22}$. The number of pupils fell throughout winter and spring 1942 due to evacuation, mobilization, and death.

Soviet schools served a combination of academic, welfare and upbringing functions. When the war began, Narkompros (The People's Commissariat of Enlightenment) demanded they continue to fulfill all three objectives as well as impart a new wartime curriculum, which emphasized foreign languages, mathematics, geography, physical education, and military training ${ }^{23}$. From the time the academic year began in 1941, Leningrad's GORONO was already struggling to meet these goals. There was a dearth of textbooks, chalkboards, and paper, which impeded classroom dictations and written homework. Air raids constantly interrupted lessons, and students and teachers shuffled between classrooms and bomb shelters several times a day. 
A typical school day was structured less by lessons than by all the interruptions to them. In light of this, school director Glafira Korneeva dismissed the idea of keeping a wartime diary because it could only be a repetitive account of all the lessons that were not taught. Ironically, she recreated such "typical" entries in her journal: "Можно проследить по журнальным записям эти перебой. Например: 8/XI читали Вишневый Сад.9/XI - урок не закончен, ВТ. 10/XI - урока не было ВТ и т. д." ${ }^{24}$ These disruptive conditions precipitated a transformation in pedagogy. According to their diaries, teachers Aleksandra Mironova, Nina Gorbunova and Ksenia Polzikova-Rubets became more flexible and minimalist in approach, drawing reading materials from newspapers and structuring lessons around discussion ${ }^{25}$.

By December 1941, hunger and cold eclipsed shortages and bombardment as the major impediments to classroom learning. Eighth-graders Maia Bubnova and Elena Mukhina and seventh-grader Valia Peterson wrote in their diaries about the tedium of sitting for hours, without electric light, in dark, frigid classrooms covered with hoarfrost ${ }^{26}$. Ink froze, making it impossible to write; hunger pangs made it difficult to concentrate. "Завтра в школу”, Bubnova wrote that January, "У меня уроки не сделаны и делать неохота. В школе холодно, замерзаешь, пока обед получаешь. Не то что 6 уроков отсидеть, а и час просидеть жутко. <..> Разве возможно что-нибудь делать при таком холоде? Я уже много раз пыталась, но мало что возможно осуществить”. Although Bubnova and her fellow Komsomol organizer Fania Abramovna tried to organize a warm room for students to do homework, the school was unable to furnish them with such a space, and the overall attitude was "lousy (настроение - дрянь)", she added ${ }^{27}$. Bubnova's journal was one of the first blockade diaries to be published, albeit in highly excerpted form. The editor cut many of her criticisms of wartime schooling but allowed the quote above to remain. Another sixteen-year-old, Yura Riabinkin, was even more emphatic, declaring that school "destroyed all my striving for knowledge because of the atmosphere in which they were conducted"28. Many schools closed in late November 1941 and those that remained functioned intermittently until May $1942^{29}$.

Even so, many students continued to attend school, many seeking social support. However, companionship also grew scarce, as attendance declined, schools closed, and students transferred to new, consolidated schools. When Elena Mukhina discovered she had been separated from the cohort with which she had studied for eight years, she was so upset that she accused the school system of deliberately trying to weaken solidarity between classmates. "Привязанность! Чувство товарищества! нет, эти понятия так же далеки от нас, нынешней молодежи, как мы от солнца" 30 .Я пришла в школу в середине ноября", Maia Bubnova explained at the start of the second blockade school year, "в новую незнакомую мне школу, которую я не знала и в которой меня не знали. <... незнакомые ребята. Ко всем нужно было привыкнуть, всех узнать и понять" 31.

Moreover, Mukhina, Bubnova, and other diarists found themselves unable to connect with their new classmates who preoccupied with other pastimes. In another 
excised passage, Bubnova despaired on her classmates' indifference, lack of energy and "бодрость” - “даже комсомольцы. С ними надо долго разговаривать, чтобы что-нибудь они сделали" ${ }^{2}$. Likewise, Mukhina regularly voiced her frustration with what she saw as the moral and academic degeneration of her new classmates. With little to buy, schoolboys were flush with cash, which fueled what she painted as an epidemic of gambling and a depreciation for money. "На переменках и во время тревог - в бомбоубежище, занимаются картежной игрой. Все переменки и даже на некоторых уроках дуются в 'очко' на деньги. А ведь это самый настоящий разврат. Я часто наблюдала за их игрой. Ведь они выигрывают зараз часто рублей 5-7, а иногда и 8. И я видела, как они теряют всякое уважение к деньгам, как небрежно бросается на пару 'в банк', 'трешка' - 3 рубля. А если случайно упадет рубль, то владелец не торопится нагнуться, чтоб его поднять, а о 20-ти копейках и говорить не стоит"з3. Mukhina not only disapproved of their activity, she was frustrated with the decline of instruction and her inability to engage her peers in meaningful conversation about their lessons or her favorite subjects of study natural science, zoology, and literature. "Я хочу, чтоб мы жили, как говорили Ленин”, she wrote in November 1941, “И чтоб школа была другая, и условия другие. Ленин сказал: 'Учиться, учиться, и учиться!' Это, по-моему, первое, о чем должен думать советский школьник! И советский школьник должен бороться со списыванием, с картами, с папиросами" 34 . Both Mukhina and Yura Riabinkin were reading Gogol's Dead Souls in October-November 1941 and were incredulous that other students either refused to read it or engage them in conversation about their favorite characters ${ }^{35}$. Mukhina and Riabinkin stopped attending school regularly in spring 1942, but Dima Afanas'ev did, and he found it difficult to connect with classmates for the opposite reason. Students were so hungry and depleted that they could barely stay awake let alone make trouble. "Ребята в классе совершенно не похожи на довоенных”, Afanas'ev wrote, “тихие, молчаливые, кажется, что они на уроках тихо дремлют и просыпаются только к кормежке. Даже обычных школьных шалостей нет. Все сидят, как усталые старички" ${ }^{36}$. In the process, such diarists recorded their observations of youth activities. Moreover, when schoolmates no longer provided much social support, they turned to their journals for solace and companionship. Some addressed their journals tenderly, asked them for advice, told them riddles, and shared their secrets ${ }^{37}$. The diary came to provide an important space of sociability and, as I will show, of academic study.

By winter 1941/1942, most diarists reported that their main motivation for attending school was food. Although some of her friends stopped attending, Valia Peterson continued to do so. "Я хожу в школу, а меня спрашивают: 'как ты еще можешь?" Peterson wrote in December 1941, "В школе хоть суп дают”з8. Elena Mukhina, who regularly took attendance in her diary, observed that most students left school after receiving their mid-day meal. "Вообще не ученики”, Elena Mukhina exclaimed, "а черт знает что" 39 . Schools' task of feeding and protecting children had eclipsed its scholastic objectives. By January 1942, geography teacher Aleksandr 
Vinokurov observed, “температура достигает -30 по $\mathrm{C}^{\circ}$. Занятия в школе прекращены. Фактически их и не было. На уроках присутствовали по 5-6 чел. в каждом классе, остальные заходили в школу, чтобы получить суп и конфетку" ${ }^{40}$. Just as students were not studying, teachers were not teaching. Writing in March 1942, Vinokurov explained that the workday for teachers - who now received Category I rations, was reduced from eight to two hours. "Ежедневно хожу в школу к 12 час. дня и в течение 2-х часов мирно беседую с коллегами. В этом заключается выполнение труд[овой] повинности" ${ }^{11}$. And in April, schools' feeding function became more-or-less officially recognized. "Школа, по решению ГОРОНО, отныне будет в большей степеней воспитательным, а не учебным заведением” 42.

Over the course of the winter of 1941/1942, students, teachers, and school administrators began to primarily associate "going to school" with eating. Sixth grader Dima Afanas'ev was among those diarists who used "school" as shorthand for "the school cafeteria” ${ }^{33}$. Afanas'ev exclaimed: “Это дополнительное питание” ${ }^{4}$. For schools to educate pupils, politically or otherwise, they had to feed children's bellies before their minds. Students were fainting from hunger, and their malnourished state made it difficult to memorize and retain information ${ }^{45}$. This proved, school director Glafira Korneeva quipped, "that 'существо определяет сознание"'46. Also evoking a Marxist tenet, sixteen-year-old Yura Riabinkin wryly echoed that wartime hunger illuminated the materiality of man because, in the fight for life "idealism was reduced to material concerns" ${ }^{47}$.

As classroom instruction declined in the winter of 1941/1942, many young blokadniki turned to their journals to draft programs of independent study. Initially, many diarists hoped that they would continue to progress through the official curriculum and grade levels. Over time, however, this motivation was joined and surpassed by more general desires to nourish the mind and distract from hunger. The diaries of sixteen-year-olds Yura Riabinkin and Elena Mukhina demonstrate this progression of motivations. "If there aren't going to be any classes at school", Riabinkin wrote, "we are going to work through (if we can!) all the courses for class nine together. We have the necessary textbooks" ${ }^{48}$. Riabinkin planned to prepare himself for exams but tragically, he did not live to reach this goal. Mukhina designed and scheduled her own curriculum, using an empty classroom for her studies. " $Я$ думаю, что если я выучу сегодня ну, предположим, географию, только что заданный урок в обстановке тишины и спокойствия, то я за три дня не смогу совершенно его забыть, а если и забуду, то на повторение уйдет очень мало. Зато, если я буду точно выполнять свой план, то я смогу много читать, дома я буду читать. Мне надо как можно скорей прочесть Дикенса (sic)‘Большие надежды’ и начать читать что-нибудь другое. Я хочу завести полочку большевика, покупать разные брошюры. Да, потом мне надо будет купить русскую грамматику и повторить все правила правописания, чтобы не обесценивать свои сочинения по литературе безграмотностью. Ну, хватит болтать, понапрасну: ‘больше дела, меныше слов!' Сейчас буду учить литературу, потом другие уроки. К этому времени Ака разогреет суп, поем, потом встану и спишу алгебру”49. 
Unwilling to let the deterioration of classroom instruction impede their academic progress, Mukhina and Riabinkin assumed the roles of pedagogue, teacher, and student. They even wielded slogans of the regime as motivation. Such ambitious educational programs helped to sustain Leningraders' spirit and morale, they also required a huge expenditure of energy. How should they allocate their energy and resources? One month after making the educational plan described above, Riabinkin highlighted how intellectual and physical survival were in tension. "I think I'll go through the subjects for the ninth year on my own", he affirmed, "I'll make the effort and study, I'll take the exams after the war and go up to the tenth grade. That seems best. But then I am not sure. None of us will survive this war"50. Still, Riabinkin strove to make progress on his schoolwork even though he had "loaves of bread" instead of algebraic formulas occupying his mind ${ }^{51}$. And though he could barely walk or lift a suitcase, the emaciated teenager resolved to take his textbooks for literature, history, and geography with him when he evacuated. In the end, because they were too weak to carry him, his mother and sister evacuated without him, and he perished in the besieged city ${ }^{52}$.

\section{Familiar Subjects, New Lessons}

The conditions of the Blockade served both as an inspiration for and an impediment to academic learning. This was phenomenon was reflected in changes that Narkompros made to the wartime curriculum, in methods Leningrad teachers used during the siege, and in diaries recording schoolchildren's independent studies and intellectual projects. In this section, I look at a few familiar school subjects - mathematics, composition, and history - to illuminate how they were broached anew by both pedagogues and diarists. In general, Narkompros advocated that teachers use every subject and lesson as opportunities for boosting morale and steeling students for war. Following their lead, young diarists approached these subjects but in their own ways that reflected the concerns and conditions of life under siege. Their journals document how mathematical computations, writing projects, and historical studies became bound up with survival, of both body and mind.

Narkompros guidelines suggested how arithmetic could teach students computation and about the superiority of the Red Army at the same time. Here is one example: "During a raid on Moscow, the anti-aircraft defense shot down first one plane, then two. Besides these, three more enemy planes were destroyed by our fighters. Calculate the German losses during the raid"53. The diarists studied their math textbooks and, outside the classroom, they also practiced mathematics as part of their fight for life. They used their journals as workbooks to compute various sums, checking their rations to make sure that they received the full amount or dividing their family's food supply in a variety of ways in order to strategize how much should be eaten today or saved for tomorrow. Elena Mukhina, for instance, used her diary to work out how the 97 rubles she had could feed her for 17 days: "хлеб $-17 \times$ (за 1 p. 70 к.) на $(17 \times 3)=857$ к. $=8$ р. 57 к." ${ }^{54}$. Similarly, other diarists calculated the 
probability of their own survival, practiced their hand at drawing tables and charts, and they solved for unknowns in scenarios drawn from their own lives. Valia Peterson and Elena Mukhina worked out the net benefits of eating one's pet, while Dima Afanas'ev and Tania Rudykovskaia calculated how food should be reapportioned after a death in the family. They learned practical economics about money management and commerce by trading and selling goods on the thriving black market. Their mathematical and economic expertise advanced naturally from the daily calculus of life under siege.

Another subject that was transformed by the war was writing. In school, Leningrad schoolchildren were asked to compose essays narrating their wartime experiences, especially with regard to patriotic duty and service. They were assigned topics such as "Schoolchildren of the Besieged city", "My part in the defense of Leningrad", and "The motherland is calling" 55 . In their diaries, some pupils simultaneously composed or planned writing projects that elucidated more personal aspects of life under siege. Elena Mukhina and her classmate Tamara, for instance, "решили писать книгу о жизни в наше время советских ребят так 9-го, 10-го классов. О мимолетных увлечениях и о первой любви, о дружбе. Вообще написать такую книгу, которую мы хотели бы прочесть, но которой, к сожалению, не существует"56. Eventually left to do this work on her own, Mukhina turned her journal into this novel, written about herself in the third person. She added an epigram to the first page of her notebook, which described its contents thusly: “...мой дневник - повесть о радостях и печалях в жизни одной уч[ениц]ы 8-го класса, о юной любви, о надеждах и разочарованиях" ${ }^{57}$. Similarly, others saw the diary itself as a way to contribute narratives of the blockade experience. Riabinkin increasingly crafted his diary as a guide for future generations about his suffering during the siege. "Mother tells me now is not the time to be keeping a diary", he admitted in October 1941, "But I will keep it. If I don't get to re-read it, someone else will reread it and will learn that there was such a person in the world as Yura Riabinkin". Once he compared the project to Gorky's Life of Klim Samgin. At times, Riabinkin worried his potential readers would laugh at him, scorn him, but the opportunity to instruct future generations drove him to continue journaling until his death ${ }^{58}$. Thus he and other pupils took up the official charge of chronicling their war experiences in their own way. Interestingly, Bubnova's, Riabinkin's, and Mukhina's diaries were eventually published, at least in part.

Like composition, history occupied a central place in the "school of the siege". Many diarists felt that history provided the key to understanding and predicting the fate of their city. “Этого, конечно, не может быть”, Dima Afanas'ev wrote, "но что бы было, если бы победили немцы? Что было бы написано про всё прошлое в учебниках истории?” Some schoolchildren channeled their anxiety about the outcome of the war into an academic quest to understand it and predict its outcome. Maia Bubnova dedicated much of her diary to this task, desperate to know "Что-то скажет история? Великая битва подходит к своему кульминационному пун- 
кту. Как-то всё это повернется? Жутко, до чего интересно!” she exclaimed ${ }^{59}$. She wrote with amusement about her friend's idea that Hitler should be punished with a history tutorial. "Она мне сказала, что если бы ей в руки дали Гитлера, то она прежде всего заставила бы его выучить историю партии на древнееврейском языке" ${ }^{0}$. For Bubnova, the siege was a great history lesson and Hitler as a poor student of history, indeed.

History had long been a subject of key political importance in Bolshevik thought and education. When WWII began, Commissar of Education Potemkin reiterated that teaching history was crucial to strengthening patriotism and devotion to the motherland: "I need to know why I love it $<\ldots>$ what I am defending, and why if necessary I am giving up my own life for it". Narkompros urged history teachers should emphasize Russia's great victories against foreign invaders, especially Napoleon's folly ${ }^{61}$. The supposed parallelism between 1812 and 1941 was also an idea widely promoted in the wartime press, beginning with Molotov's 1941 announcement of Germany's invasion and pronouncement of it as a second Great Patriotic War.

Given the regime's investment in history as a political tool, it provides a particularly useful demonstration of how the diarists' independent studies sometimes placed them at odds with the Party line. Working on their own, schoolchildren drew different conclusions from this historical pairing. Dima Afanas'ev, for instance, had a keen interest in military uniforms and made it a habit to study local guardsmen and images of Red Army men. When he observed that they were wearing breastplates and epaulettes, he considered this through a historical lens, concluding: "Похоже, что теперь начинается поворот к старым порядкам. Не хватает только, чтобы еще эполеты, аксельбанты и “ваше благородие’ вернули”62. Implicit in Afanas'ev's observations is a rather subversive charge that the Soviet regime was in danger of replicating the social stratification of the imperial period. It was not Hitler, but the USSR that stood poised to learn about the revenge of history. Moreover, elaborating on the parallelism between 1812 and 1941, Afanas'ev observed that Leningraders "выглядят страшновато: худые, желтые, с вывалившимися глазами, грязные, закутанные, как солдаты Наполеонсковой (sic) армии в 1812, кто во что..." - not the heroic defenders of the city of Lenin ${ }^{63}$. Therefore, in his own attempt to adopt and apply this historical framing to his surroundings, Afanas'ev, perhaps inadvertently, contradicted the official narrative of Russia's military past. The disorderly, disruptive conditions of blockade schools created space for more flexibility, variety, and personal initiative in their studies.

In addition to 1812, the siege of Petrograd in 1918 was another common point of comparison for Leningraders. While teachers and journalists alike upheld 1918 as an inspirational example of how their city heroically withstood a brutal siege and extreme hunger, schoolchildren drew a wider variety of conclusions from the analogy. The comparison illuminated for Yura Riabinkin that "what we are enduring now is worse than that experienced in 1918". Summarizing some key features of the Petrograd siege, Riabinkin pointed out that one could buy food by leaving the city or 
from profiteers and black marketeers more easily than in his day, where the isolation was so extreme and food so scarce that money ceased to hold much value ${ }^{64}$. For Maia Bubnova, the 1918/1941 comparison also highlighted the extremity of her current situation, and she chided her prewar self for idealizing war as the “героическая сказка" of the Civil War that was reproduced in the wartime press ${ }^{65}$. At the same time, she drew very different lessons about 1918 than Riabinkin. Bubnova's interpretations were cast through Konstantin Fedin's Cities and Years. The novel takes place in war-torn Petrograd - home to "те же окопники, те же карточки, тот же суровый, настороженный, ощетинившийся" as Leningrad. But for Bubnova, it provides a lesson in what not to do. She railed at the protagonist, Andrei Startsov, as "не человек а труха", with no sense of purpose, no strength of will, and worst of all, who places romantic love ahead of the collective. The novel's moral, she argued, was as pertinent for Leningrad in 1941 as it was in 1919: collectivism was the key to survival and fulfillment. If you live in a collectivist spirit, she reasoned, “... то все свои личные невзгоды ты перенесешь легче и сумеешь победить в себе отчаяние, найдешь волю и силу, чтобы вновь и вновь добиваться, сумеешь вместе со всеми построить то, что никогда бы не сумел один" ${ }^{\prime \prime}$. And when she encountered defeatism and egoism, including at the factory where she worked, Bubnova apparently treated her compatriots to a fiery history lecture that drew on the revolutionary years 1905 and 1917-1919. "От кого это я слышу? Кто это говорит? Настоящие ли советские граждане <...> это говорит не пролетарий, рабочий... вот что идеал их жизни, хоть подхалим. Сволочи!" she wrote contemptuously of her coworkers. Most of this text was cut from the published edition of her diary. Despite her disgust, Bubnova frequently recorded such overheard conversations not just as examples of anti-Soviet thought but as social data - "Интересно все-таки, кто что говорит", she admitted ${ }^{67}$.

History lessons, both official and unofficial, readily emerged from wartime shortages. Given the lack of textbooks, some Leningrad teachers crafted lessons based on newspaper articles, radio broadcasts, and other contemporaneous material ${ }^{68}$. History teacher Aleksandra Mironova described one such lesson in her diary, where she read aloud newspaper articles to lead the children in a discussion: "Все смотрели на меня <...> вопрос у всех: 'А как вы думаете, победим мы, гитлеровцев или нет?' Читаю выступление по радио т. Сталина. Коля Лебедев говорит: 'нужно всем вот так работать, как сказал т. Сталин, всё по-военному и, наверное, наши все-таки победят'. 'Расскажите', просят меня ребята, 'как боролись раньше в 1918 и Алекс[андр] Невский’. Мы еще долго сидели. Я рассказывала детям”69. Other teachers, such as Ksenia Polzikova-Rubets, also described this pedagogical method of using news articles to foster class discussion. Pravda and Sovetskaia Pedagogika especially honored Leningrad teachers for inspiring patriotism and boosting morale in their students ${ }^{70}$. Interestingly, this approach represented a departure from the teacher-led instruction espoused by the Stalinist educational model of the mid-1930s, which emphasized the instructor authority, student discipline, individu- 
al achievement, rote memorization, and drills. By contrast, the minimalist and more student-centered style of blockade lessons are reminiscent of Soviet pedagogical styles of the 1920s. However, this wartime shift was born of necessity and conflicted with official educational policy ${ }^{71}$. In the 1954 published version of her diary, Polzikova-Rubets applauded the return of teacher-led instruction in spring $1942^{72}$.

Still, teachers' diaries do suggest how the conditions of the Blockade fostered student independence and initiative, both inside and outside of the classroom. For instance, after he stopped attending school in the winter of 1942, Dima Afanas'ev dutifully replicated classroom curriculum by generating his own discussions of the lessons contained in the news. This work often led him to conclusions that were directly opposed to the authors' intentions. Without the teacher there to guide him, he attended more to the lack of information in the articles than their rousing messages. Why were no specific place or personal names were given? "Почему всё время пишут только направления и не пишут, какие города сдают или берут обратно? или это военная тайна?"73 Even when names were mentioned, Afanas'ev's suspicion that Leningraders were being deliberately misinformed did not subside. Each time he read about heroic pilots, he assumed it masked a discouraging reality: “...почему то всё время награждают главным образом летчиков. Видимо, на земле наши воют хуже, чем в воздухе" 74 . The "туманная" nature of news reports turned reading into an exercise in textual interpretation.

During the Blockade, learning, studying, and self-improvement remained central to many students' lives and therefore to their diary accounts. However, the devastation of Leningrad's school system compelled them to relocate their educational pursuits outside of the classroom. This shift toward independent, self-directed learning precipitated a temporary, but radical transformation in the educational activities and intellectual habits of young Leningraders. The siege permitted more flexibility and self-initiative in education, and it recast familiar subjects - including mathematics, composition, and history - in a new light, bound up with survival. As a result, schoolchildren sometimes approached their studies in ways that conflicted with official curricular and pedagogical guidelines.

\section{Studying Pedagogy}

As they designed and conducted their studies, some young diarists became interested in pedagogy, textbooks, and teaching methods. Ironically, their commitment to the regime's didactic mission, hampered by the conditions of the siege, led them to assume an authoritative and somewhat critical stance on the instructional techniques they encountered. One of the main areas of scrutiny was political education, which Elena Mukhina, Maia Bubnova, and others claimed had suffered along with other aspects of schooling under siege. Mukhina and Bubnova make an interesting pairing because, while the former admitted she had been called anti-Soviet ( $a n$ tisovetskonastroennyi) by teachers in the past for her careless spelling and lack of 
diligence, the latter was a model student who led her school's Komsomol organization $^{75}$. In their diaries, both eighth graders modeled the role of educationalist not only by creating their own curricular programs but by critiquing their schools' programs in political education. Echoing Narkompros, Mukhina wrote in late November 1941 that instructors must not only teach but "reeducate" (перевоспитывать) students, transforming them so that "мы бы стали советскими школьниками, коммунистами в душе <...> и чтоб каждый из нас твердо решил прожить свою жизнь по-настоящему. Стать действительной сменой наших родителей, быть лучше родителей. Культурней, образованней. И самим стать такими родителями, чтоб вырастить детей своих еще лучше, чем мы сами <... > Боже мой, как мне хочется, чтобы начали перевоспитывать ребят" ${ }^{\text {". }}$. Mukhina's earnest commitment to the regime's pedagogical mission led her to question the efficacy of wartime schooling.

Equally devoted to Soviet instruction, Maia Bubnova critiqued another educational program at her school, the Komsomol. In November 1942, the age for admission to the Komsomol was lowered from sixteen to fourteen in order to replenish its numbers and extend its influence over Soviet youth. For Bubnova, however, this posed a direct threat to the efficacy of the organization's educational and political mission, for it meant she had to admit unqualified, "poor students". In a long tirade (which the editor cut from the published version of her diary), Bubnova declared that, under these new policies, the Komsomol was not uplifting students but falling to their level, encouraging underachievement. "Я с болью в сердце принимала в комсомол некоторых ребят, буквально под давлением райкома комсомола”, and its secretary Comrade Shcherbakova. According to Bubnova, Shcherbakova believed that a young blokadnik had earned admission by virtue of his suffering: "Pa3 он пережил блокадную зиму, значит он достоин быть комсомольцем”. However, the diarist argued that a recruit must be a good student or expelled from the ranks if his grades slipped. In her journal, Bubnova mocked this leadership style: “...почувствовали себя чем-то вроде капризных школьников, за которыми бегают няньки, упрашивая идти в школу и вести себя прилично, быть сознательным ребенком. Это просто безобразие!” By contrast, Bubnova argued, “нужно воспитывать хорошими встрясками и требованиями, как к взрослым людям" "7. Although she was determined to enhance the power of the Komsomol and extend the influence of Bolshevik ideals, the decline of instruction during the siege as well as the decimation of the student ranks led Bubnova to interrogate the organization's leaders, policies, and tolerance for lower academic standards. In sum, just as they used their diaries as study spaces for advancing their studies, the Mukhina and Bubnova also turned to them to critique educational authorities.

Beyond political education, pedagogical methods and texts continued to absorb young diarists. After she became an orphan in February 1942, Elena Mukhina rarely attended school. So, instead of imploring teachers to mold and instruct her, she stayed home and read old schoolbooks she found in friends' apartments or discarded about the city, drawing her own scholastic, personal, and political insights from 
them. One was Jonathan Franklin's Natural History for Educated Readers and Young People (Volume One), published in Russia in 1862 and antiquated by the standards of Stalinist pedagogy. Moreover, the subject of natural history was significantly reduced by the new wartime curriculum. So, Mukhina studied it on her own. The textbook was not only academically instructive, it helped her to cope, to survive, to imagine a brilliant future for herself as a zoologist. She fantasized about a time after the war when she would be well fed. Unlike the dark, cold, and empty rooms she inhabited in Leningrad, her Moscow apartment would be filled with life - aquariums of fish, terrariums of mice, and flapping birds. "Всё свое чувство привязанности, какое было у меня к моей маме и Аке, я переложу на моих маленьких жильцов”, she wrote in March 1942. Natural History helped Mukhina to envision and write new circumstances for herself beyond the heartache and hunger that the siege inflicted. Mukhina also took notes on Franklin's inspirational wisdom more than on his scientific claims. One passage struck a chord with her: "В минуты испытания или нравственного бессилия иногда достаточно человеку, любящему природу, изучавшему ее, случайно остановить взор на маленьком цветке, услышать пение птички, жужжание насекомого - и вот сердце его обновилось надеждой"78.

Mukhina became engrossed in other, archaic textbooks in the spring of 1942, drawing her own lessons and insights from them. She was intrigued by "a very curious" children's literary primer she found in a neighbor's home, Klavdiia Lukashevich's The Sower: A Child's First Reader (Сеятель: первая после азбуки чтения в школе и семъe), which was first published in St. Petersburg in 1907. The eighth grader studied it from the perspectives of both student and teacher. Mukhina praised the work's instructional style and moral teachings - a notable contrast from her criticism of her own political education. "Мне очень нравится, что в то время детей с самого детства учили любви к родителям, к природе, добру" Mukhina copied out sections of the primer. Interestingly, the passages she gravitated toward would have been anathema to Soviet textbooks, including folk and religious proverbs, poetry about Christmas Day festivities, and the story of Jesus's birth ${ }^{80}$. In the absence of regular schooling, Mukhina developed a commitment to and growing interest in education, studying on her own and often drawing unorthodox lessons from the textbooks and pedagogical methods she discovered - intellectual relics of a bygone era.

While Mukhina was absorbed in pre-revolutionary texts, ten-year-old Yuri Maretin was drawn to the pedagogical theories of the 1930s. Before he began regularly attending school again in fall 1942, Maretin explained that his "school" was his desk and his teachers were the many books in the family's library ${ }^{81}$. Maretin studied and evaluated each book in the reading diary he kept under siege. While he loved novels and adventure stories, Maretin wrote his longest entry about A. S. Makarenko's three-volume epic Pedagogical Poem. This autobiographic work tells the story of how Makarenko reeducated orphans and juvenile delinquents, turning them into disciplined Soviet citizens with a collectivist ethos. Makarenko 
suggested that this transformation could be better achieved through struggle and rigorous self-discipline than through traditional schooling. That insight resonated with ten-year-old Maretin, struggling to survive in blockaded Leningrad. Like Mukhina, Maretin also studied Makarenko's work from a pedagogical perspective, hailing it as "замечательная книга не только для педагогов, но и для обыкновенных людей.” The third-grader even defended the educational theorist from rival pedagogues, whom he called "кабинетные профессора" and whose ideas were "абстрактны и стары”. “Я только ругаю себя, что слишком поспешно читал, не всё запомнил”, Maretin wrote in his diary ${ }^{82}$.

In their attempts to personalize, replicate, and interiorize various forms of Soviet pedagogy, Bubnova, Mukhina, and Maretin developed their own views on the current state of instruction and teaching methodology employed in the classroom.

\section{$* * *$}

After the second siege school year drew to a close, the flow of supplies into the city and of evacuees out of Leningrad greatly improved. Schools began to reopen and the students who remained began to attend more regularly. Amid this process of recovery and restoration, officials proclaimed that education in blockaded Leningrad was a tremendous success. Leningrad schools and orphanages were showcased in Pravda, in the educational press, and in exhibitions across the Soviet Union as shining examples of both the children's heroism and the regime's commitment to them. Inside the city, children delivered this message by dancing, singing, and reciting poems for state and party leaders ${ }^{83}$. And they were honored - for defensive work, community service, and academic studies - by receiving the same honors as adults. Thirty-six thousand Leningrad youths were decorated; 15,000 of them received the coveted medal "For the Defense of Leningrad (за оборону Ленинграда)" ${ }^{\text {. }}$.

Despite all of the self-congratulation, a myriad of educational reforms promulgated in summer 1943 and throughout 1944 belied official concerns about losing control over schooling - and thus over the political development, intellectual training, and disciplining of Soviet youth - during WWII. Coeducation was terminated in major cities and curriculum became gender specific. Uniforms as well as tighter controls over attendance, grading, and student deportment were introduced ${ }^{85}$. Leningrad's schools, which were cut off from Kremlin authorities the longest, became a major target of these new directives. Several of them were enforced there before they became national policy. After two years of upheaval, city officials regained control over the scholastic activities of Leningrad children.

The years 1941-1943, however, were a time of tremendous intellectual energy, especially outside of the classroom. The Blockade brought unprecedented challenges to Soviet schooling, but it also fostered a great deal of academic activity and growing interest in pedagogy among young blokadniki. Beset by school closures and disrupted classes, some youngsters turned to their diaries as workspaces, where they 
documented the conditions of wartime education as well as took notes on various lessons - academic, personal, political, social. The journals they kept showcase both young Leningraders' commitment to the regime's educational mission as well as how they inadvertently departed from that agenda. Taking up the mantle of Soviet education, they designed their own programs of study, composed alternative narratives, revisited antiquated textbooks, and sometimes drew unorthodox conclusions from the wartime press and historical analogies. Their wartime engagement with mathematics, composition, history, and political education yielded insights that were bound up with blockade life but were unconventional by official curricular standards.

In their diaries, these young schoolchildren played the roles of instructor, pedagogue, and pupil. And their accounts are indeed instructive about the broader meaning of education under siege. This idea is reflected in an epigraph, which Elena Mukhina added to her diary, promising readers a great educational experience if they opened her journal. “Считай потерянным для себя тот день, когда ты не узнал ничего нового, не научился ничему полезному!”

1 For examples of this language in adults' diaries, see: Irina Zelenskaia, entries 9/IX/41 and 11/IX/41 / Tsentral'nyi gosudarstvennyi arkhiv istoriko-politicheskikh dokumentov, SanktPeterburg (TsGAIPD). F. 4000. Op. 11. D. 35. L. 13-14, 36 ob.; Natalia Osipova, entries 6/ VIII/41 and 28/XII/41 // TsGAIPD. F. 4000. Op. 11. D. 89. L. 4, 11.

2 Zelenskaia, entry 25/XI/41. L. 36 ob.

3 Ksenia Polzikova-Rubets, entry 22/VI/41 // Oni uchilis' v Leningrade: dnevnik uchitel'nitsy. Leningrad: Gosudarstvennoe izd-vo detskoi literatury ministerstva prosveshcheniia RSFSR, 1954. P. 10. This source is hereafter "Polzikova-Rubets (1954)". There are significant differences between the 1954 edition of her diary, the 2000 edition, and the archival version in TsGAIPD.

4 Nina Erokhana (née Klishevich), entry 21/VIII/41 // Gosudarstvennyi memorial'nyi muzei oborony i blokady Leningrada (GMMOBL). F. RDF. Op. 1L. D. 490. L. 13. Also see: Erokhana, entry 15/VI/42. L. 34-35.

5 Recounted in: Dunstan J. Soviet Schooling in the Second World War. New York: St Martin's Press, 1997. P. 96-97, 100, 103.

6 Selivanov V. Stoiali kak soldaty: Blokada. Detei. Leningrada. St. Petersburg: Ego, 2002. P. 73; Snigirev $S$. F. Deiatel'nost' zhenshchin v leningradskom gosudarstvennom pedagogicheskom institute im. A. I. Gertsena v gody velikoi otechestvennoi voiny // Zhenshchina i voina: o roli zhenshchin v oborone Leningrada, 1941-44: Sbornik statei. St. Petersburg: Izd-vo Sankt Petersburgskogo Universiteta, 2006. P. 118.

7 Of the many important studies on Soviet education, I am particularly indebted to: Cherkin S. A. Sovetskaia obshcheobrazovatel'naia shkola v gody Velikoi otechestvennoi voiny. Moscow: Pedagogika, 1984; Dunstan J. Soviet Schooling...; Sedova N. V. Shkola v gody voiny // Zhenshchina i voina; Selivanov V. Stoiali kak soldaty.

8 Dunstan J. Soviet Schooling... P. 165.

9 Other examples include: Sergei Ezerskii's syndicated Leningradskaia Pravda article "This is How We Live" from November 1941; Nikolai Tikhonov's series of articles in December 1942 for Moskovskaia Pravda on the children in Leningrad's Orphanage N 58; Polzikova-Rubets' 1943 article "Odna iz shkol goroda-fronta" in Sovetskaia Pedagogika, N 10. P. 49-54. 
10 Fadeev A. A. Leningrad v dni blokady (iz dnevnika). Moscow: Sovetskii Pisatel', 1944. P. 61.

${ }^{11}$ Werth A. Leningrad. New York: Alfred A. Knopf, 1944. P. 81, 82.

12 Kuraronok N.G., Kudriashova L.S. Nas zheg ogon' smertel'nyi! Vospominaniia uchitelei Frunzenskogo raiona o voine 1941-1945. St. Petersburg: AMOS, 1995. P. 52.

13 HellbeckJ. Revolution on My Mind: Writing a Diary under Stalin. Cambridge: Harvard University Press, 2006. P. 38-41; Holmes L. Stalin's School: Moscow's Model School N 25, 19311937. Pittsburgh: University of Pittsburgh Press, 1999. P. 48-51.

14 Stenograficheskii otchet RK VKP(b) g. Leningrada, 26/XI/41 // TsGAIPD. F. 4000. Op. 10. D. 776. Also see: Peri A. The War Within: Diaries from the Siege of Leningrad. Cambridge, MA: Harvard University Press, 2017.

15 Collective diaries in: Nichto ne zabyto: 320 stranits o 900 dniakh v blokade Leningrada, 19411944. St. Petersburg, 2005. P. 246; Skorb' i radost'. P. 20; Okhta Porokhovye. P. 26-27; Selivanov $V$. Stoiali kak soldaty. P. 73. On exhibits of children's diaries, see: Nina Gorbunova, entry 1/II/43 // TsGAIPD. F. 4000. Op. 11. D. 27. L. 27. Gorbunova managed Orphanage N 58.

16 HellbeckJ. Revolution on My Mind.

17 On the financial and emotional cost of diary-writing under siege, see: Tatiana Grizova-Rudykovskaia (née Rudykovskaia), entries 16, 30/IV/42 // GMMOBL. F. RDF. Op. 1R. D. 1. L. 12-15.

18 Historians often date Stalinist school reform to the Central Committee's resolution of $25 \mathrm{Au}-$ gust 1931. It, and several directives that followed, expanded the number of schools and standardized curriculum, textbooks, grading, and discipline (Fitzpatrick S. Education and Social Mobility in the Soviet Union, 1921-1934. Cambridge: Cambridge University Press, 1979. P. 222-224).

19 Soviet schools were often understaffed and undersupplied, and there was a persistent gap between policy and practice (Ewing E. Th. The Teachers of Stalinism: Policy, Practice, and Power in Soviet Schools of the 1930s. New York, Peter Lang, 2002. P. 65-72; Holmes L. Stalin's School. P. 158). Still, the upheaval wrought by WWII was unprecedented.

20 Sedova N. V. Shkola v gody voiny. P. 98-99, 101.

21 David Glantz gives different figures: 3295 highly explosive and 67,078 incendiary bombs (Glantz D. The Siege of Leningrad, 1941-1945: 900 Days of Terror. London, 2001. P. 78.

22 Figures from: Sedova N. V. Shkola v gody voiny. P. 98-99; Selivanov V. Stoiali kak soldaty. P. 18, 22, 76. By 1943, circumstances and resources improved. During the 1943/1944 school year, 124 schools served more than 36,000 children. In the 1944/1945 academic cycle, the number of schools was just under 200 (Sedova N. V. Shkola v gody voiny. P. 102).

23 Dunstan J. Soviet Schooling. P. 91-92; Sedova N. V. Shkola v gody voiny. P. 98, 103.

24 Mukhina, entries 23, 29/XI/41, 16/XII/41. L. 58 ob., 60 ob., 64 ob.; Glafira Korneeva, entry 13/IX/42 // TsGAIPD. F. 4000. Op. 11. D. 51. L. 33. Korneeva was a schoolteacher at School N 16 before she was sent to Orphanage 27. Later, she was a school inspector, a kindergarten manager, and director of School N 3 in the Sverdlovsk district.

25 Dunstan notes that textbook shortages made war news a popular teaching tool throughout the USSR. He also suggests that dictation, composition, and copying off the blackboard remained key pedagogical methods - a different picture than that which emerges in Leningrad teachers' diaries (Dunstan J. Soviet Schooling. P. 130-131).

26 Valia Peterson, entry 9/X/41 // TsGAIPD. F. 4000. Op. 11. D. 86. L. 2; "Iz dnevnika Maii Bubnovoi”, entry 27/XI/41 // Leningradtsy v dni blokady. Leningrad, 1947. P. 223-224. This source is hereafter "Bubnova (1947)".

${ }^{27}$ Bubnova (1947), entry 14/I/42. P. 228.

28 Riabinkin, entry 1/XII/41 // Adamovich A., Granin D. Leningrad Under Siege: First-hand Accounts of the Ordeal / Transl.: C. Burstall and V. Kisselnikov. Barnsley: Pen and Sword, 2007. P. 113.

29 Because of constant interruptions, GORONO mandated the fall 1941 term be repeated in May and June 1942 (Okhta, Porokhovye. P. 29; Selivanov V. Stoiali kak soldaty. P. 194; Sedova N. V. Shkola v gody voiny. P. 101, 107). 
30 Mukhina, entry 11/XI/41. P. 50.

31 Bubnova, entry 6/VII/43 // TsGAIPD. F. 4000. Op. 11. D. 18. L. 16 ob. - 17. This archival version of her diary is hereafter "Bubnova (1943)".

32 Compare entry 31/I/42 // Bubnova (1947). P. 228 and entry 23/I/42 // Bubnova (1943). L. 12 ob. -13 .

33 Mukhina, entry 22/XI/41. P. 56.

34 Mukhina, entry 27/XI/41. P. 60.

35 Riabinkin, entry for 6-7/XI/41 // Adamovich A., Granin D. Leningrad Under Siege. P. 100; Mukhina, entry 27/XI/41. P. 59.

36 Afanas'ev, entry 12/V/42. P. 38. Afanas'ev and his family fled to Leningrad from Gatchina to escape occupation. Between school closures, falling ill, and moving to new apartments, Afanas'ev and his brother Yuri sporadically attended school, and evacuated in summer 1942. Thanks to Natal'ia Aleksandrovna Afanas'eva for permission to use her late husband's diary. This unpublished manuscript of Afanas'ev's diary is hereafter referred to as "Afanas'ev (1942)". When the texts match, I cite the published edition in: Staleva T. Vechnyi Deti Blokady: dokumental'nye ocherki. Moskva, 1995. That source is referred to as "Afanas'ev (1995)”.

37 Examples in: Mukhina, entries 29/XI/41, 11/X/41. P. 22, 25; 26/IV/42. P. 57, 49-50, 110-113.

38 Peterson, entry 25/XII/41. L. 6 ob. -7.

39 Mukhina, entry 1/XII/41. L. 61 ob. She took attendance in: Ibid, entries 1, 16/XII/41. L. $61 \mathrm{ob} ., 64 \mathrm{ob}$.

40 Blokadnyi dnevnik uchitelia Vinokurova, A. I., entry 23/I/42 // Blokadnye dnevniki i dokumenty. St. Petersburg: Evropeiskii Dom, 2004. P. 243. This source is hereafter "Vinokurov". He taught geography at Schools N 5 and N 72 before leaving to work as a voenruk in School N 169. In 1943, he left teaching to work on the October Railroad, and he was arrested for "counterrevolutionary and anti-Soviet agitation". While his diary was confiscated as evidence, almost none of his criticisms of the school system were underlined by the NKVD as incriminating.

41 Vinokurov, entry 27-30/III/42. P. 255.

42 Vinokurov, entry 4/IV/42. P. 258.

43 Examples of this shorthand among pupils: Mukhina, entries 25-27/II/42. L. 85 ob., 93 ob.; Dmitri Afanas'ev (1942), entries 8/V-30/VI/42. L. 128-151; among teachers: Valentina Ivleva, entries 11/XI/41 and 2/XII/41 // GMMOBL. F. RDF. Op. 1L. D. 431. L. 9 - 9 ob.; Korneeva, entry 29/IX/42. P. 42-3.

44 Afanas'ev (1942), entry 5/V/42. P. 126-127.

45 Polzikova-Rubets (1954), entry 13/XI/41. P. 50-51; Lidiia Zabolotskaia, entry 25/I/43 // TsGAIPD. F. 4000. Op. 11. D. 30. L. 19 - 19 ob. On memory loss and pedagogy, see: PolzikovaRubets (2000), entry 31/XII/41. P. 10; Polzikova-Rubets (1954), entry 17/XII/41. P. 66.

46 Korneeva, entry 6/X/42. P. 54.

47 Riabinkin, entry 1/XII/41. P. 357.

48 Riabinkin, entry 1/IX/41. P. 41.

49 Mukhina, entry 23/XI/41. P. 58.

50 Riabinkin, entry 15/IX/41. P. 292.

${ }^{51}$ Riabinkin, entry 29/X/41. P. 97.

52 Riabinkin, entry 29/XI/41. P. 110-111. On his death, see: Ibid, 200-202.

53 On the militarization of academic subjects, see: Dunstan J. Soviet Schooling. P. 127-130.

54 Mukhina, entry 13/II/42. L. 83. Examples of charts in: Ibid, entry 25/I/42. L 80 ob.

55 Dunstan J. Soviet Schooling. P. 140.

56 Mukhina, entry 16/XI/41. L. $51 \mathrm{ob}$.

57 Mukhina. L. 1.

58 Riabinkin, entry 25/X/41. P. 96-97.

59 Afanas'ev (1995), entry 17/VI/42. P. 41; Bubnova (1943), entry 14/XII/41. L. 7 ob.

60 Bubnova (1943), entry 4/XII/41. L. 7. 
61 On the Central Committee's 1931 decree “on strengthening historicism," and similar directives, see: Fitzpatrick S. Education and Social Mobility. P. 230-231; Kelly C. Children's World, Growing Up in Russia, 1890-1991. New Haven: Yale University Press, 2007. P. 534-536; Dunstan J. Soviet Schooling. P. 135-136, 146.

62 Afanas'ev (1995), entry 22/V/42. P. 38.

63 Afanas'ev (1995), entry 22/III/42. P. 34. In his manuscript, Afanas'ev originally wrote "1912” instead of "1812."

64 Riabinkin, entry 30/XI/41. P. 113.

65 Bubnova (1943), entry XI/41. L. 4 ob. -5 ob. No specific date was given for this entry.

66 Bubnova (1947), entry 20/XII/41. P. 225-226.

67 Bubnova (1943), entries 1/X/41 and 25/XII/41. L. 3 - 3 ob., 9 ob.

68 Dunstan J. Soviet Schooling. P. 130-131.

69 Mironova, entry 10/VII/41. P. 5. Also see: Gorbunova, entries 27/X-2/XI/42, and 27/I/43. L. 12 ob. -13 ob., 26 ob.

70 See Polzikova-Rubets' history lessons about the Russian empire's battles with Genghis Khan, Karl XII, and Napoleon (Polzikova Rubets (1954), entry 2/XII/41. P. 61-62).

71 Eroing E. Th. The Teachers of Stalinism. P. 151-158; Kelly C. Children's World. P. 95-96, 125, 535-539; Konecny P. Builders and Deserters: Students, State, and Community in Leningrad, 1917-1941. Montreal: McGill and Queen's University Press, 1999. P. 154-161; Fitzpatrick S. Education and Mobility. P. 222-224. Several educational policies resembled those of the Civil War era, including full day kindergartens, but this was due to practical more than ideological concerns (Kirschenbaum L. Small Comrades: Revolutionizing Childhood in Soviet Russia, 1917-1932. New York: Routledge, 2001; Konecny P. Builders and Deserters. P. 4-5, 152).

72 Polzikova-Rubets (1954), entry 14/IV/42. P. 94-95.

73 Afanas'ev (1995), entry 14/VIII/41. P. 16.

74 Afanas'ev (1995), entry 15/VII/41. P. 11.

75 On the anti-Soviet accusation: Mukhina, entry 18/XII/41. L. 65 ob. -66 ob.

76 Mukhina, entry 27/XI/41. L. 59 ob. -60.-

77 Bubnova (1943), entry 6/VII/43. L. 16 ob. - 17 ob. Also see: Ibid, entries 23/I/42 and 2/ IX/43. L. 12 ob. $-13,18$ ob. -19.

78 Mukhina, entry 21/III/42. L. 95 - 95 ob.

79 Mukhina, entry 13/IV/42. L. 105 ob. - 106. Mukhina studied the 1917 edition of the book.

${ }^{80}$ Mukhina, entry 12/IV/42. L. 104 ob. - 105 ob.

81 Maretin planned to start school in 1941, but due to closures and problems at home, he did not regularly attend until September 1942, when he started third grade at School N 319. This information is drawn from an interview with Maretin in: Staleva T. Pust' znaiut zhivushchie... Khudozhestvenno-dokumental'nye ocherki. Moscow: MPI, 1991. P. 8-14.

82 Maretin's diary // Staleva T. Pust' znaiut zhivushchie... P. 8-9.

83 In December of 1942 Nikolai Tikhonov visited Gorbunova's orphanage to document it as a success story for Moskovskaia Pravda. On these performances, see: Rudykovskaia, entries 13-14/ XI/43. P. 55; Gorbunova, entries 20/XII/42 and 1/II/43. P. 19, 27; Sedova N. V, Shkola v gody voiny. P. 102; Polzikova-Rubets (1954), entries 17, 18/XII/41 and 21/I/42. P. 66-67, 81; Polzikova-Rubets (2000), entry 3/III/42, 47, 13-14/XI/43. On the exhibitions, see: Dunstan J. Soviet Schooling. P. 157.

${ }^{84}$ Sedova N. V, Shkola v gody voiny. P. 100-101.

85 Exing E. Th. Separate Schools: Gender, Policy, and Practice in Postwar Soviet Education. DeKalb: Northern Illinois University Press. P. 32-38; Shtuman D. The Soviet Secondary School. New York, 1988. P. 59; Kelly C. Children's World. P. 118, 539, 542-543; Sedova N. V. Shkola v gody voiny. P. 99; Selivanov V. Stoiali kak soldaty. P. 86, 187-192.

86 Mukhina. L. 1 ob. 